\title{
Youth unemployment in old Europe: the polar cases of France and Germany
}

Pierre Cahuc ${ }^{1}$, Stéphane Carcillo ${ }^{2}$, Ulf Rinne ${ }^{3,5^{*}}$ and Klaus F Zimmermann ${ }^{4}$

\author{
* Correspondence: rinne@iza.org \\ ${ }^{3}$ IZA, Bonn, Germany \\ ${ }^{5}$ Institute for the Study of Labor \\ (IZA), Schaumburg-Lippe-Str. 5-9, \\ 53113 Bonn, Germany \\ Full list of author information is \\ available at the end of the article
}

\begin{abstract}
France and Germany are two polar cases in the European debate about rising youth unemployment. Similar to what can be observed in Southern European countries, a "lost generation" may arise in France. In stark contrast, youth unemployment has been on continuous decline in Germany for many years, hardly affected by the Great Recession. This paper analyzes the diametrically opposed developments in the two countries to derive policy lessons. As the fundamental differences in youth unemployment primarily result from structural differences in labor policy and in the (vocational) education system, short-term oriented policies do not address the core of the problems. Ultimately, the youth unemployment disease in France and in other European countries has to be cured with structural reforms.
\end{abstract}

JEL codes: J24; J38; J68

Keywords: Labor policy; Labor market institutions; Great recession; Youth unemployment; Minimum wages; Demographic trends; Vocational education and training; Employment protection

\section{Introduction}

The Great Recession broadly affected labor markets around the world, but individuals in vulnerable positions were strongly hit-including the young generation. Although entry into the labor market already posed major challenges before the crisis, the Great Recession has intensified cross-country differences. Among others, Bell and Blanchflower (2010, 2011a, 2011b) analyze this new rise in youth unemployment after the crisis with a particular focus on the United Kingdom and the United States. In fact, while in some countries youth unemployment was hardly affected during these times of trouble, it dramatically increased elsewhere and reached new record highs. This demonstrates the crucial role that institutional settings and public policies can play in influencing school-to-work transitions.

France and Germany are two extreme cases in Europe. Whereas Germany has hardly been affected by rising youth unemployment, France is one of the European countries in which a "lost generation" of young individuals who enter the labor market under the current adverse economic conditions could become a tragic reality. How to effectively tackle the youth unemployment problem has therefore become a major concern and policy issue in Europe-not only because of its immediate negative impacts, but also because early adulthood unemployment creates long-lasting scars affecting labor market outcomes much later in life (Schmillen and Umkehrer, 2013).

(c) 2013 Cahuc et al.; licensee Springer. This is an open access article distributed under the terms of the Creative Commons Attribution License (http://creativecommons.org/licenses/by/2.0), which permits unrestricted use, distribution, and reproduction in any medium, provided the original work is properly cited. 
However, before starting any policy action, it should be clearly understood how youth unemployment can be tackled most effectively. Therefore, to select measures that successfully target the roots of the problem, this paper aims to provide empirical evidence for informed policy decisions. More specifically, we focus on the question of why Germany performs exceptionally well in terms of youth unemployment while France does not. The interactions of economic and demographic factors, along with labor market institutions, are central in explaining cross-country differences in youth unemployment. Our analysis thus considers the following aspects separately: a) the Great Recession's impact on labor demand patterns, the economic structure and economic growth; b) labor market institutions, labor policies, education and vocational training designed to enhance the labor market prospects for disadvantaged youths; and c) demographic trends, in particular the size of younger cohorts determining young people's labor supply.

The remainder of this paper is organized as follows. Section 2 presents stylized facts which lead us to conclude that France and Germany are indeed two polar cases in the debate about rising youth unemployment in Europe. Then in Sections 3, 4 and 5 we explain the differences in youth unemployment between the two countries by separately analyzing the Great Recession's impacts, labor market institutions and labor policies for youths, and demographic trends. We summarize concrete policy proposals to fight youth unemployment in France in Section 6 and discuss policy responses and general lessons in a broader perspective in Section 7. Finally, we conclude in Section 8.

\section{The polar cases of France and Germany}

Figure 1 shows the development of youth unemployment in the United States and Europe from 2000 to 2012. Clearly, there has been a strong rise in youth unemployment on both sides of the Atlantic after the beginning of the Great Recession in late 2008. However, there are significant differences in the respective levels. In the early 2000s, European youth unemployment had already been about twice as high as in the United States. The Great Recession's impacts have to some extent reduced this gap, but the European

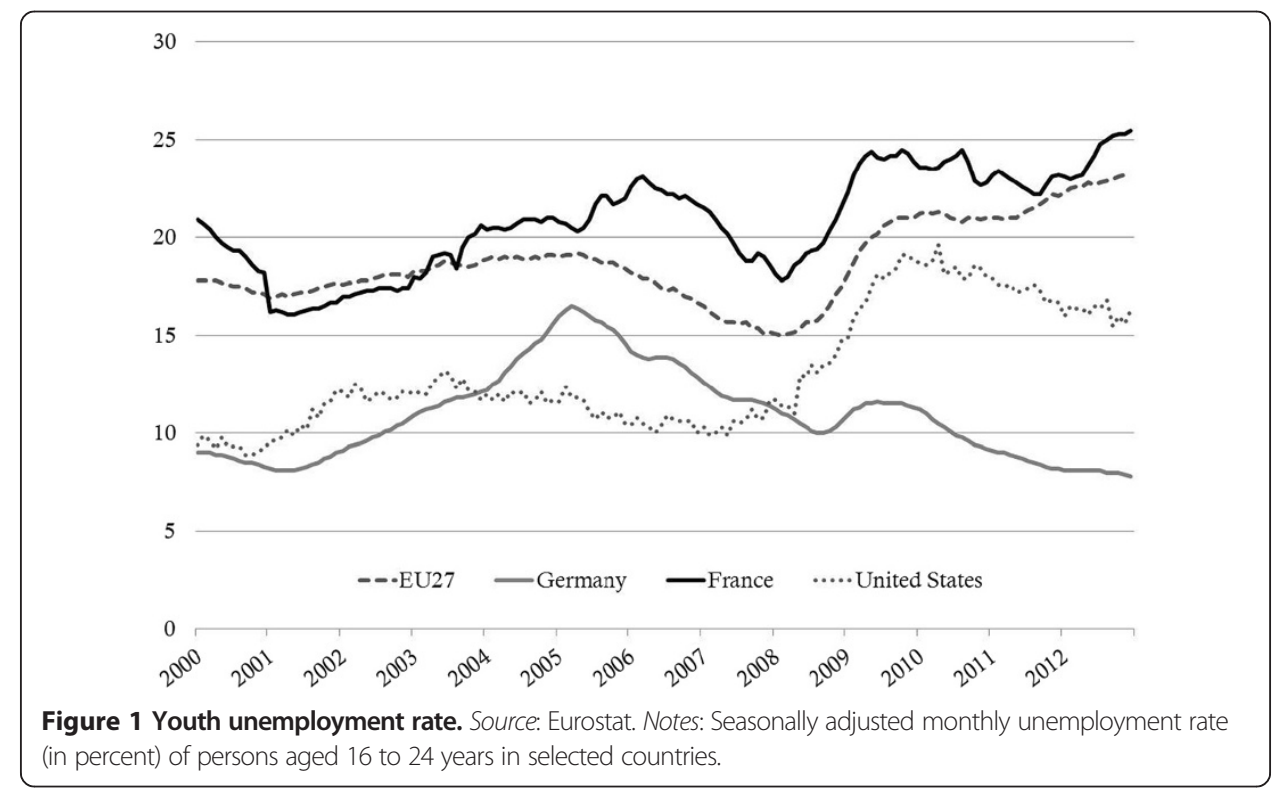


Union's figures still by far exceed those of the United States. By the end of 2012, youth unemployment in the European Union stood at 23.3 percent, while it was at 16.3 percent in the United States. ${ }^{1}$

Within the European Union, however, there is a substantial degree of heterogeneity in youth unemployment. France and Germany can be viewed as two extreme cases in this regard. In the first case, France basically follows the pattern that can be seen across the European Union, albeit on a slightly higher level. For example, by the end of 2012, the French youth unemployment rate was at 25.5 percent. On the other hand, youth unemployment in Germany has been falling relatively steadily since its peak in the beginning of 2005. Even the Great Recession had only a modest and short-term impact; and by the end of 2012, the youth unemployment rate stood at 7.8 percent in Germany.

Even though unemployment is a key socio-economic indicator, it only provides a partial view of youth's situation. For instance, it does not provide information about individuals outside the labor force. While some are inactive, many of those aged 16 to 24 are still in the education system. As a result, the share of active youth in this age group is often small. Furthermore, in some countries students often combine work and education and therefore are looking for a job. For this reason another useful indicator is the share of youth which is not in employment, education, or training, also called the NEET rate. This category is comprised of youth either looking for a job (while not studying), or inactive (often discouraged).

Figure 2 shows how this rate evolved in the United States and Europe from 1997 to 2011 among youth aged 15 to 19 years (Panel A) and 20 to 24 years (Panel B). Trends and differences across countries turn out to be similar to those observed for the unemployment rate. For the youngest group, the NEET rate is of comparable size between the United States and Europe; however, it is strikingly lower in Germany compared with the European average (notably with France) as well as the United States. The difference has been relatively constant and only slightly growing during the 2000s. Thus, Germany now boasts a rate twice as low as France at 3.5 percent.

Among those aged 20 to 24 , the NEET rate is two to three times larger than it is for the younger group and much more volatile in all countries. This reflects the fact that many young people finish their initial education and enter the labor market at this age. However, the same differences between countries can be observed: a declining rate in Germany, now almost twice as low as in France and Europe at 12.5 percent in 2011. For this age group, France now features one of the highest rates in Europe, at 20.5 percent, just behind Spain, Italy and Greece (between 25 to 30 percent). However, it is worth noting that the striking differences in this age group have emerged only since 2005, when France and Germany shared a similar NEET rate.

France and Germany are thus two polar cases with respect to youth unemployment and inactivity in Europe. However, what factors can explain this diametrically opposed pattern? As pointed out above, the Great Recession had different impacts on youth unemployment in the two countries. Hence, we analyze this issue in greater detail in the next section.

\section{Impacts of the great recession}

If the impact of the Great Recession had been different between France and Germany, it would at least partly explain the different development of youth unemployment in 

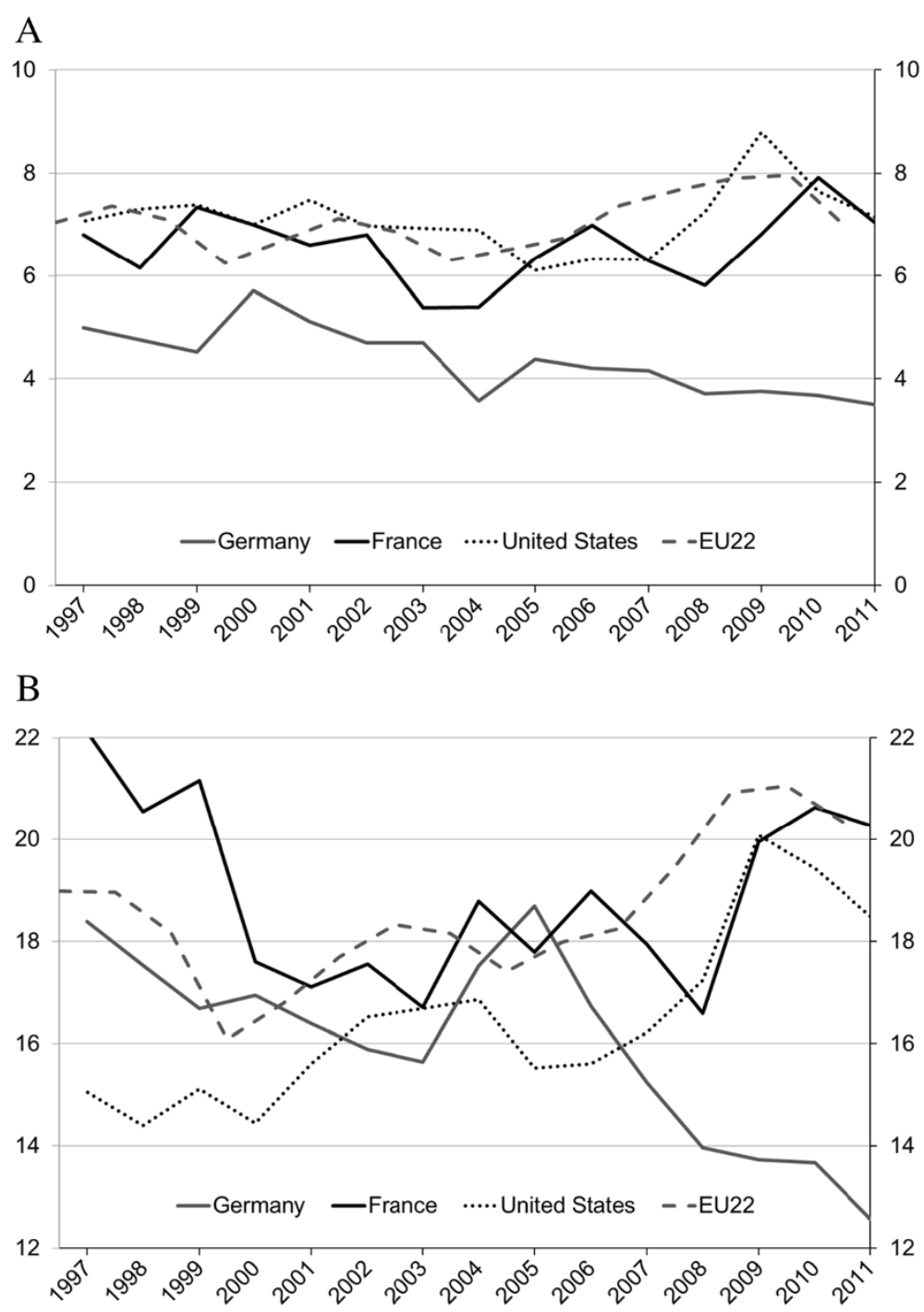

Figure 2 NEET rates. Panel A: age 15-19 years. Panel B: age 20-24 years. Source: OECD Education database. Notes: The NEET Rate is the share of individuals in the age group not in employment, education or training.

these two countries. Figure 3 thus displays the Great Recession's impact on Gross Domestic Product (GDP). Accordingly, output declined to a similar extent on both sides of the Atlantic, although countries in the European Union were on average even more strongly affected than the United States. However, the largest output drop in all countries was in early 2009.

When comparing output decline between France and Germany, the impact of the Great Recession in terms of GDP was apparently weaker in France. The output drop in Germany exceeded both the average in the European Union and even the one in the United States. On the other hand, recovery took place earlier and was stronger in Germany than in France and the European Union average. Already by 2010, Germany performed just as well as France and the United States when using the respective GDP pre-recession values as a benchmark. Hence, the Great Recession's impact on GDP was not too markedly different between the countries considered here. If anything, one may conclude that its immediate impact on output was smaller in France than in Germany, 


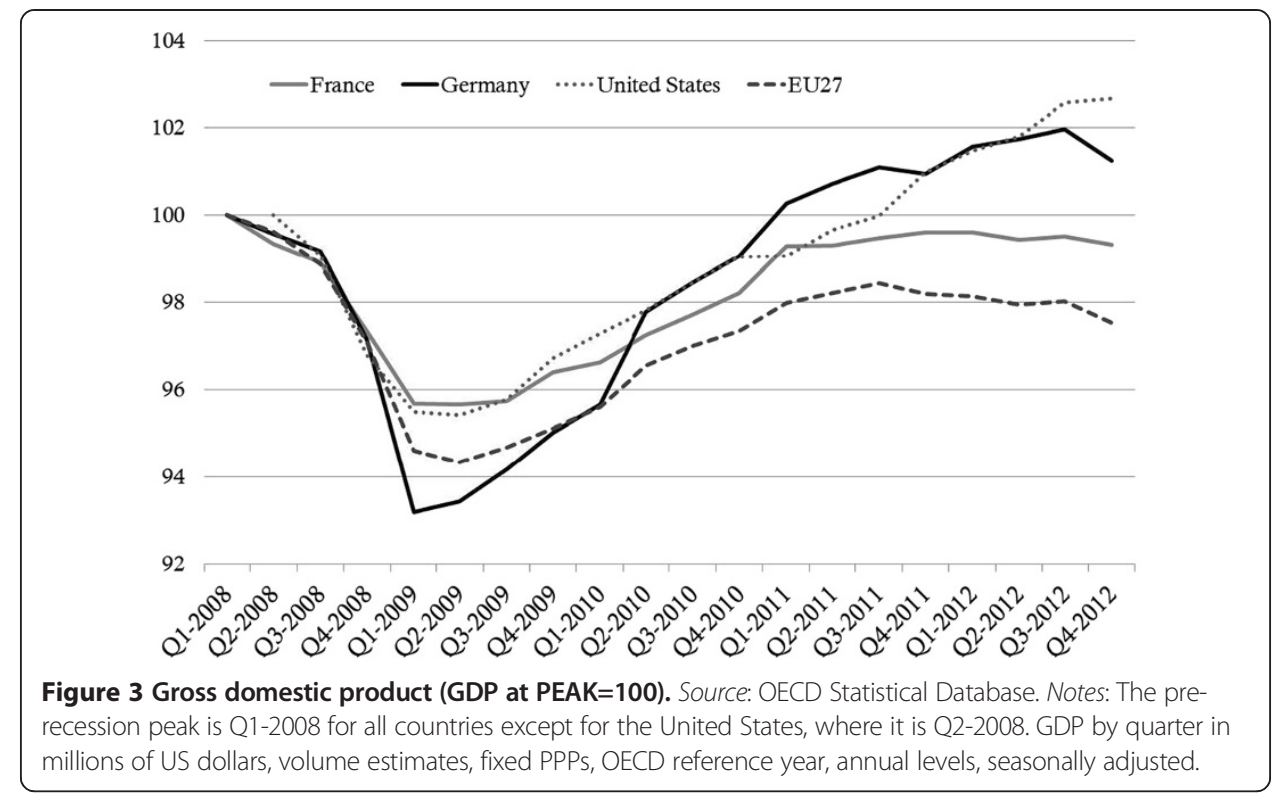

but recovery was both earlier and stronger in Germany. However, the crisis' impacts on the labor markets may have been different.

And indeed, Figure 4 shows that the labor market impacts of the Great Recession greatly varied between countries. Adult unemployment rates have generally increased since late 2008, but the extent to which they have increased-and subsequently decreased (or not)-is very heterogeneous. Adult unemployment in the United States strongly increased. It more than doubled from roughly 4 percent to more than 8 percent in 2009 and 2010. But since then it has been falling, and by the end of 2012, it was at 6.5 percent. In contrast, adult unemployment in the European Union did not increase as strongly. Although it reached a similar magnitude of about 8 percent in 2009 and 2010, it had already been at a higher level than in the United States before the crisis started. Importantly, adult unemployment has continued to increase since 2011 in the European Union while it has been falling in the United States.

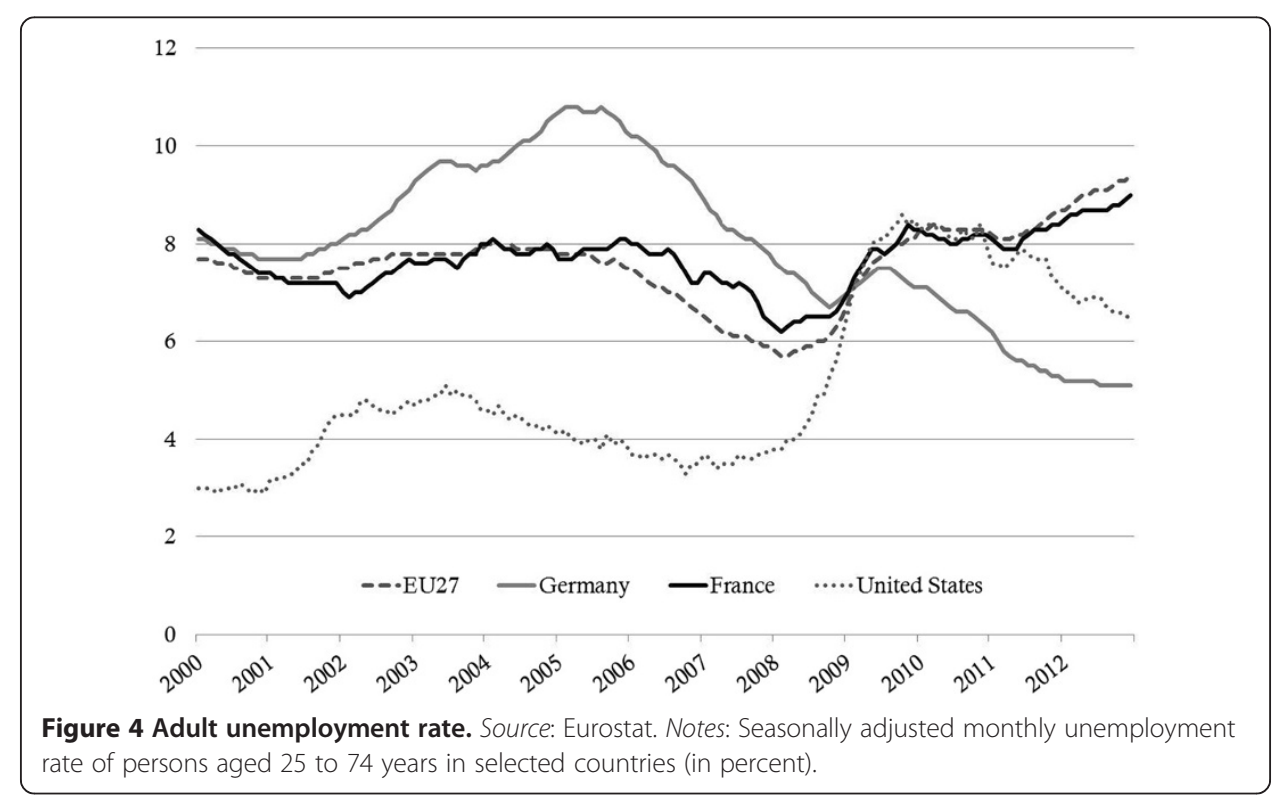


Adult unemployment in France closely resembles the pattern observed for the entire European Union. It therefore noticeably increased during the Great Recession and has not fallen since. By the end of 2012, adult unemployment in France was at 9 percent. In stark contrast, the crisis had only a very modest impact on adult unemployment in Germany. Its steady decline since the peak in 2005 has been just briefly interrupted, but otherwise adult unemployment has continued to fall. By the end of 2012, it stood at 5.1 percent.

The resilience of Germany's labor market during and after the Great Recession is very remarkable-and exceptional. Sometimes labeled as a "new economic miracle," the country's success story has received a lot of attention and several studies analyze its underlying mechanisms. Representative for this literature, Rinne and Zimmermann $(2012,2013)$ argue that the interaction of different factors resulted in employment adjustments mainly at the intensive margin. Among these factors is the specific nature of the economic shock that hit Germany (mainly export-oriented sectors were affected), the concrete policy responses during the critical period (e.g., short-time work), the significant reforms that had improved the functioning of the labor market ("Hartz reforms"), and long-term demographic trends that are expected to result in shortages of skilled labor.

Although the Great Recession's impact in terms of GDP was similar in France and Germany, the French labor market was much more strongly affected than the German one. This is true in terms of both adult and youth unemployment. Although this fact can explain at least part of the differences in youth unemployment between the two countries that we currently observe, it is important to additionally consider the development of the youth-to-adult unemployment ratio over time. By doing so, two additional questions can be answered. First, one can assess whether adults and youths were affected by the crisis to a similar extent. Second, the youth-to-adult unemployment ratio can be viewed as an indicator of potentially existing structural problems with the labor market integration of youths in a given country.

Figure 5 displays the youth-to-adult unemployment ratio during the period from 2000 to 2012. For the European Union, this ratio has practically been constant over time,

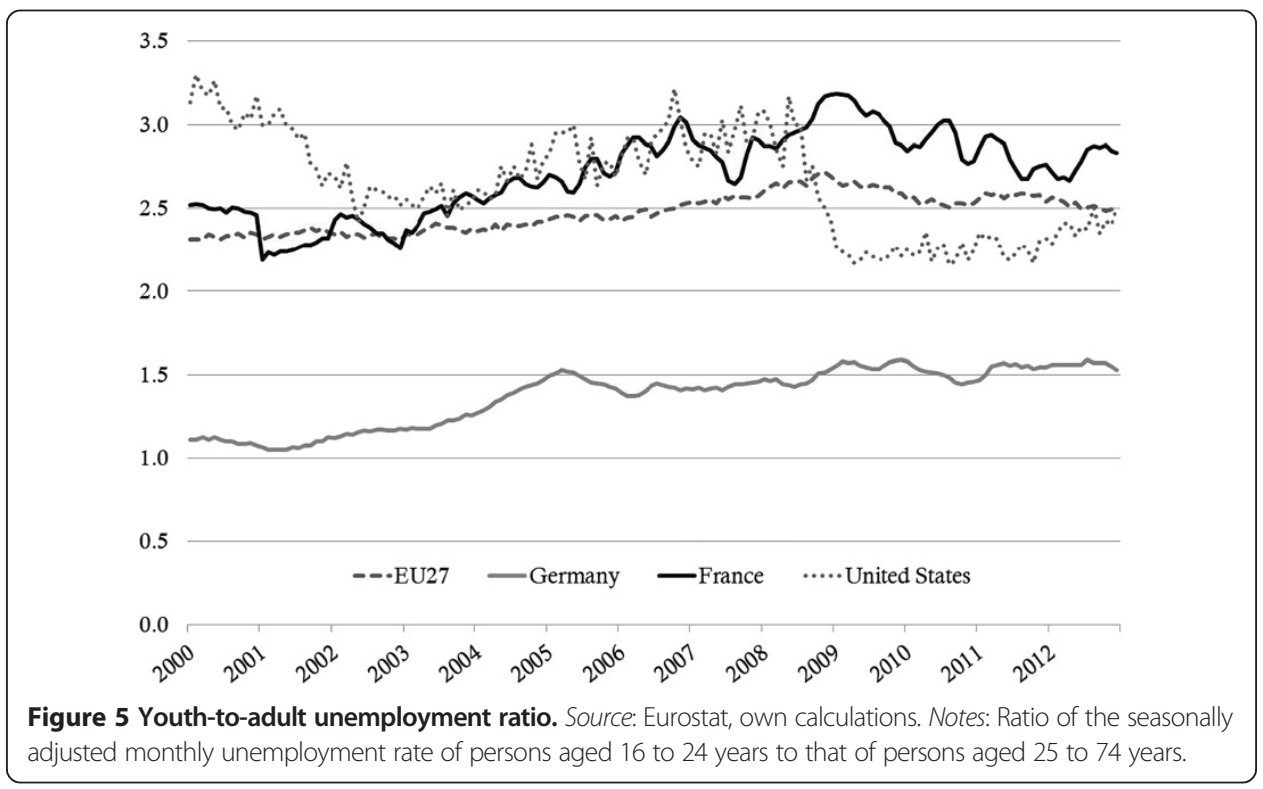


rising slowly until 2008 and falling thereafter. During this period, youth unemployment was about 2.5 times higher than adult unemployment. Importantly, we do not observe any substantial impact of the Great Recession on this ratio in the European Union. Therefore, the two age groups were similarly affected by the crisis. In contrast, the youth-to-adult unemployment ratio substantially dropped in the United States at the start of the Great Recession. While it had been at around 3.0 until 2008, it fell to less than 2.5 afterwards. Thus, in the United States, the crisis affected youths to a much smaller extent than what could have been expected.

The youth-to-adult unemployment ratio in Germany has been at a very exceptionally low level, close to 1.0 in the early years. Although it significantly increased during the early 2000s, it has been around 1.5 since 2005 when the labor market reforms took place. Consequently, we do not observe any effect of the Great Recession. In France, the ratio is notoriously high, with values rising over 3.0 in 2009 but falling below 3.0 thereafter. This ratio remains above the European Union's average, however. This is first evidence that structural differences in youth unemployment exist between France and Germany.

To further assess this issue, we perform a decomposition exercise. More specifically, we decompose the evolution of youth unemployment into a component which is specific to youths (the youth-adult ratio) and another which refers to the older population (the adult unemployment rate). Based on the observation that the youth unemployment rate can be expressed as the product of the adult unemployment rate and the youth-to-adult unemployment ratio, we calculate two counterfactual youth unemployment rates. For counterfactual 1, we take the German youth-to-adult unemployment ratio and multiply it by the French adult unemployment rate. Comparing this with the actual French youth unemployment rate should give us a solid impression about the extent to which country differences are due to youth-specific factors (i.e., due to differences in the extent to which unemployment affects young and older individuals differently in the two countries). For counterfactual 2, we multiply the French youth-to-adult unemployment ratio by the German adult unemployment rate, and compare it again to the actual French youth unemployment rate. Relying on the observations that the German adult unemployment rate was hardly affected by the crisis and the youth-to adult unemployment ratio remained approximately constant in France, this analysis should reveal the importance of factors that affect the unemployment rate of the whole population in France.

Figure 6 displays the results of this counterfactual analysis. When focusing first on counterfactual 1, we clearly see the importance of youth-specific factors in explaining the differences in youth unemployment between the two countries. If France had faced the same youth-to-adult unemployment ratio as Germany, its youth unemployment rate would have actually been lower than the German rate-at least until 2009. After the Great Recession had hit both countries, the situation changed. Counterfactual 2 indicates that factors affecting unemployment more generally gained importance since then. The German labor market was very resilient to the economic shock (Rinne and Zimmermann, 2012, 2013) which made the overall economic situation, especially in terms of unemployment, substantially more favorable in the German context. However, youth-specific factors still play a very important role as counterfactual 1 remains well below the actual French youth unemployment rate, also during the crisis. 


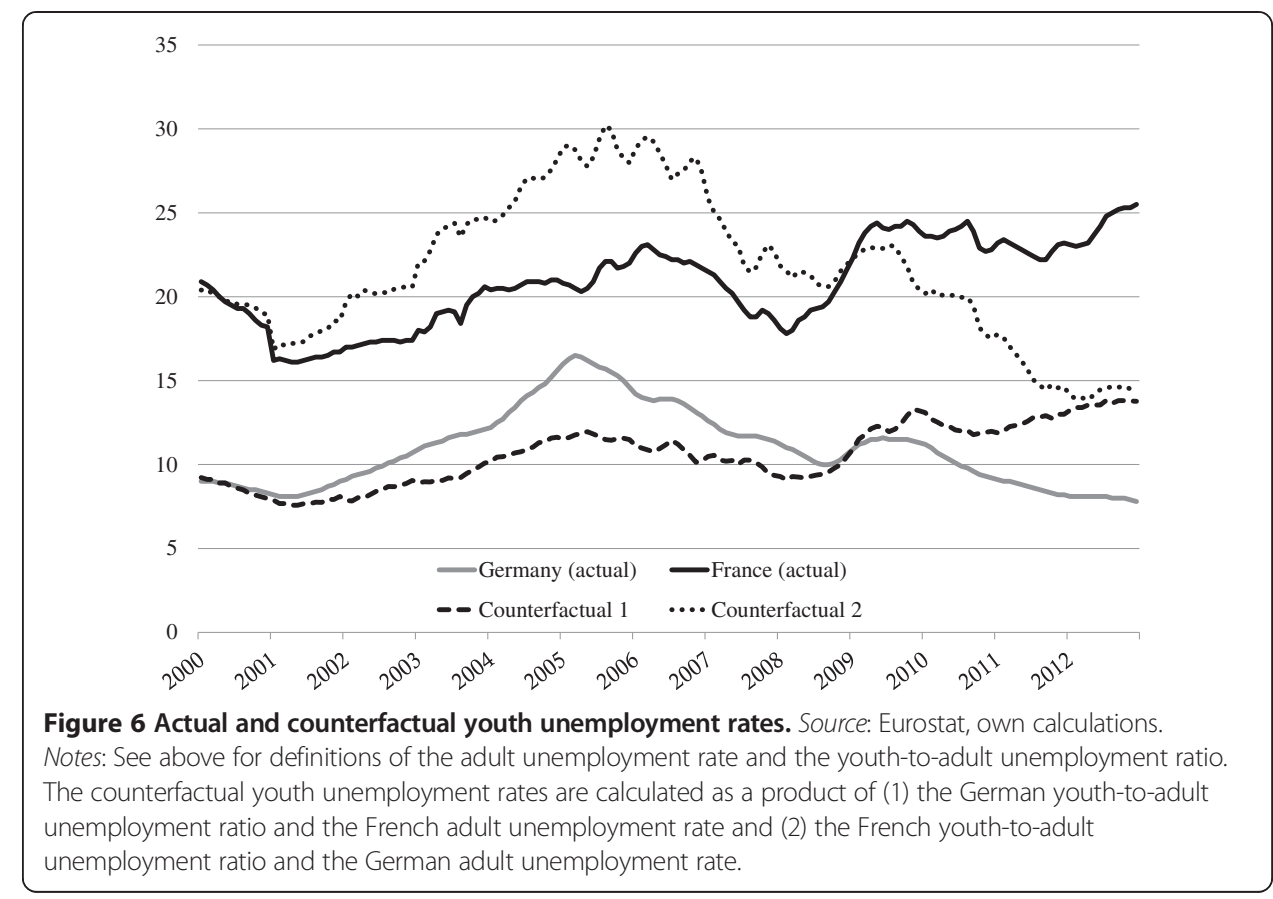

It is therefore important to analyze the labor market institutions and policies that shape youth labor market integration in France and Germany. This is done in the next section.

\section{Labor market institutions and labor policies}

Institutional settings and public policies can play a crucial role in influencing school-towork transitions. As shown above, the French youth-to-adult unemployment ratio-as well as the NEET rate-are about twice as high as in Germany. We therefore assess which labor market institutions and labor policies can explain these structural differences. Our analysis focuses on the following issues: a) vocational education and training; b) minimum wages and employment protection; and c) activation measures and labor policies. In addition, as labor market entry poses a particular challenge for low-qualified youths, our subsequent analysis has a special focus on this population group.

\section{Vocational education and training}

Education plays a key role in the risk of becoming unemployed or inactive. For instance, in France, 85 percent of NEETs have not studied beyond secondary school. This is even more worrisome as the school dropout rates are particularly high and continue to worsen. More than 150,000 young people, or 20 percent, leave the school system each year without any qualifications.

Many studies show that vocational education and training is able to smooth the transition from school to work (see, e.g., Eichhorst et al., 2012, for an overview). Hence, it is not surprising that training in combination with practical (subsidized) work experience in the private sector is the most efficient way to ensure sustainable unsubsidized employment, whereas employment in the public sector has no significant impact (Card et al., 2010).

Like Austria and Switzerland, Germany has a dual apprenticeship system. Besides the standard curricula, these three countries have established a professional system combining work experience, on-the-job training and classroom teaching (the last is usually provided 
in a special type of school such as the Berufsschule in Germany). In these countries, this form of vocational training represents the main path of transition from school to work. For example, about two-thirds of the youths completing general schooling each year enter the dual apprenticeship system in Germany and about one-fifth participate in full-time vocational schooling (Biavaschi et al., 2012). In addition, the share of apprentices who stay in the same firm after completing their apprenticeship has been about 60 percent in recent years (Grunau, 2011). These figures demonstrate the importance and success of this system in Germany.

German apprentices typically sign a three year training contract with a firm, in which they alternate between school- and firm-based training. ${ }^{2}$ Over 50 percent of all companies with at least one employee are entitled to conduct this type of training. In addition, apprenticeship training is provided in basically all sectors of the economy. Firms bear the costs of workplace training facilities and pay apprentices a standardized salary (about $€ 600$ to $€ 700$ per month in 2011). The firms' incentives to provide this form of training include the accumulation of firm-specific human capital, using it as a screening device, and demonstrating social commitment.

The returns to completing dual apprenticeship training are significant in Germany. Not only do roughly two-thirds of those who successfully complete training subsequently enter employment, but participants also have a faster entry into the labor market when compared to those in school-based vocational training (Parey, 2009). Furthermore, the dual apprenticeship system significantly improves wages and employment stability when compared to individuals with "schooling only" (Adda et al., 2011). After 3 to 4 years, about 80 percent are employed (of whom 60 to 70 percent are in "stable" employment relationships). Their wage profile is similar to university students in early years, but flatter in later years. For example, Clark and Fahr (2001) estimate substantial annual returns to apprenticeship training and also provide evidence supporting the transferability of training across occupations. ${ }^{3}$

Nevertheless, even though the German dual apprenticeship can be regarded as a success story, there are also challenges that this system faces. One challenge is related to problems of demand and supply. More specifically, employers' willingness to train is correlated with economic conditions and thus, the availability of apprenticeship positions follows a cyclical pattern. Furthermore, firms prefer committed and engaged apprentices. They mostly require a minimum level of "trainability" which some youths are unable to meet. Hence, there are limited options for low-qualified youths. Youths with low schooling have no other training option than participating in the dual apprenticeship system. Youths unable to enter this system thus face a high risk of marginalization. The current solution to this problem is the extensive provision of "preparatory" training programs, although the most disadvantaged do not benefit (Caliendo et al., 2011).

As a more general challenge, dual apprenticeship systems rely on the broad support of employers, trade unions and the government for regulation and financing. In particular, their success critically depends on the trade unions' willingness to accept apprenticeship contracts which are paid below the level of standard contracts-in exchange for a commitment from employers to offer practical training. The support of the government involves not only developing special vocational schools and training qualified teachers, but also offering preparatory training for young people who are not yet ready to start an apprenticeship after leaving school. This "pre-apprenticeship" training is essential 
for low-qualified young people-in particular, when access to the dual system is as competitive as it is in Germany (Caliendo et al., 2011). As a consequence of such broad support, vocational training via apprenticeships is widely recognized by young people, their parents and society as a solid pathway to employment in Germany, Austria and Switzerland.

An apprenticeship system is also in place in France. Students pursuing the vocational track within the education system can either enroll in full-time vocational schooling or in on-the-job apprenticeships with part-time study at training centers. Both routes prepare students for the same tests and diplomas. The number of young people beginning apprenticeships has doubled over the last 20 years (Cahuc et al., 2013). However, this increase during the last 10 years is entirely due to relatively qualified young people, i.e., youths who already hold an equivalent or better diploma than the secondary school leaving exam. Although various forms of direct subsidies to employers hiring apprentices exist (e.g., exemptions from social security contributions, hiring bonuses), some businesses, in particular small firms, are reluctant to hire apprentices. Course content and expectations for the final exam prove to be an additional challenge. For example, while reading and mathematics can be regarded as essential skills for any job, it appears questionable whether the performance in primarily academic subjects should be decisive to obtaining a diploma-at least, as long as the purpose of the diploma is not to access higher education.

However, one should not expect immediate results from any changes to the French model. For example, the German apprenticeship model was developed over decades through close and continuous dialogue with the social partners aimed at establishing and regularly updating training courses for each type of qualification. This model has ensured that every detail is discussed and negotiated, including the duration of apprenticeships, expectations for the final exam, course contents and pay levels.

\section{Minimum wages and employment protection}

Labor costs can be an important barrier in the transition from school to work-in particular for low-qualified job seekers. A number of studies show the detrimental employment effects for young people when a minimum wage is set too high (Abowd et al., 2000; Kramarz and Philippon, 2001; Neumark and Wascher, 2008). ${ }^{4}$ As a general rule, studies on labor demand effects estimate that a 1 percent increase in labor costs reduces employment of the low-skilled, a group in which unemployed youths represent a large proportion, by 1 percent (Cahuc and Carcillo, 2012).

Labor costs in France are characterized by a minimum wage level that is the highest amongst OECD countries with regards to 20 year-old workers (Cahuc et al., 2013). Monthly labor costs at the current French minimum wage amount to $€ 1,616$ for a fulltime position. This creates not only a substantial barrier for low-skilled job seekers to access employment, but it is also a complex issue for society. A large number of young people in France are not sufficiently qualified to be as productive as the minimum wage requires them to be. ${ }^{5}$ This certainly limits their chances of finding a job. While other countries allow a reduced minimum wage for young people compared to adults, France has not adopted such an approach-apart from select exceptions. ${ }^{6}$

Germany follows a different approach. There is no national statutory minimum wage, but minimum wages are negotiated by industry and occupation among the social partners. 
They can be declared as legally valid for a whole market segment by a governmental commission. In principle, the state does not intervene in this process much, at least so far. ${ }^{7}$ Figure 7 displays the result. Excluding apprentices, 30 percent of low-skilled young Germans who are employed have labor costs between $€ 7$ and $€ 10$ per hour. However, it should be noted that the German welfare system generates an implicit minimum wage, which may similarly act as a barrier to access employment for youths. Müller and Steiner (2009) calculate the implicit minimum wage as the hourly wage which would yield the same net income in a full-time job as long-term unemployment benefits. They find an implicit minimum wage of less than $€ 5$ per hour (around $€ 600$ per month) for singles without children, which is the typical situation for youths in Germany. ${ }^{8}$ Moreover, if youths still live in a household with their parents, they will typically have no access to these benefits since eligibility is assessed at the household level. Welfare generosity should thus not provide disincentives for German youths.

A related argument in the German context is that job quality has deteriorated in general, with an increased segmentation of the labor market and an increased share of low-pay work. However, these issues are not particularly age-related, but are rather driven by skill levels and occupational change (Eichhorst et al., 2013b, p.81). The vast majority of skilled younger workers still have decent prospects of entering open-ended contracts in Germany. This is also the case for those who have successfully completed a dual apprenticeship.

Nevertheless, there is a popular myth that German labor market reforms have created a growing low-wage sector with precarious jobs. The introduction of a statutory minimum wage thus appears as the "silver bullet" in the political sphere to combat this unintended side effect. However, who would actually be affected by-and potentially benefit from-a minimum wage of $€ 8.50$ or $€ 10$ ? These are the values currently being discussed. Figure 8 shows that actually only a small fraction of full-time employees would be affected. On the other hand, larger fractions which would be affected include the marginally employed,

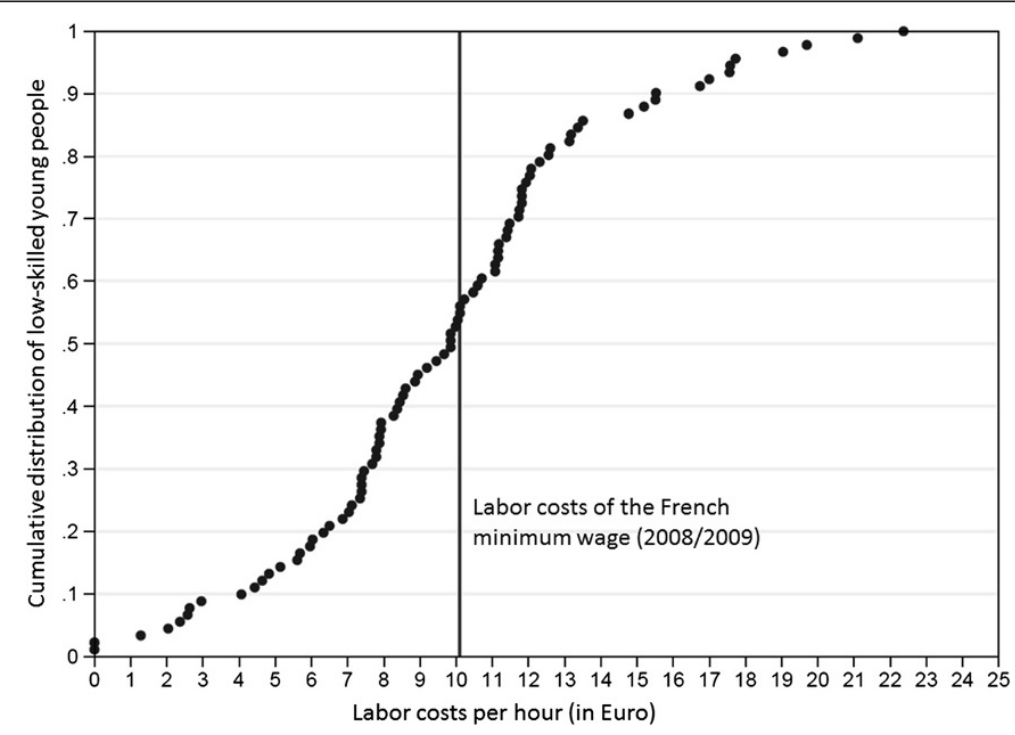

Figure 7 Labor costs of employed youths in Germany (2008/2009). Source: German Socio-Economic Panel (GSOEP), own calculations. Notes: Age 20 to 25 years. Excluding those youths in apprenticeships, in terms of hourly labor costs in 2008/2009. Explanation: 55 percent of young Germans cost their employer less than the equivalent cost of the minimum wage in France. 


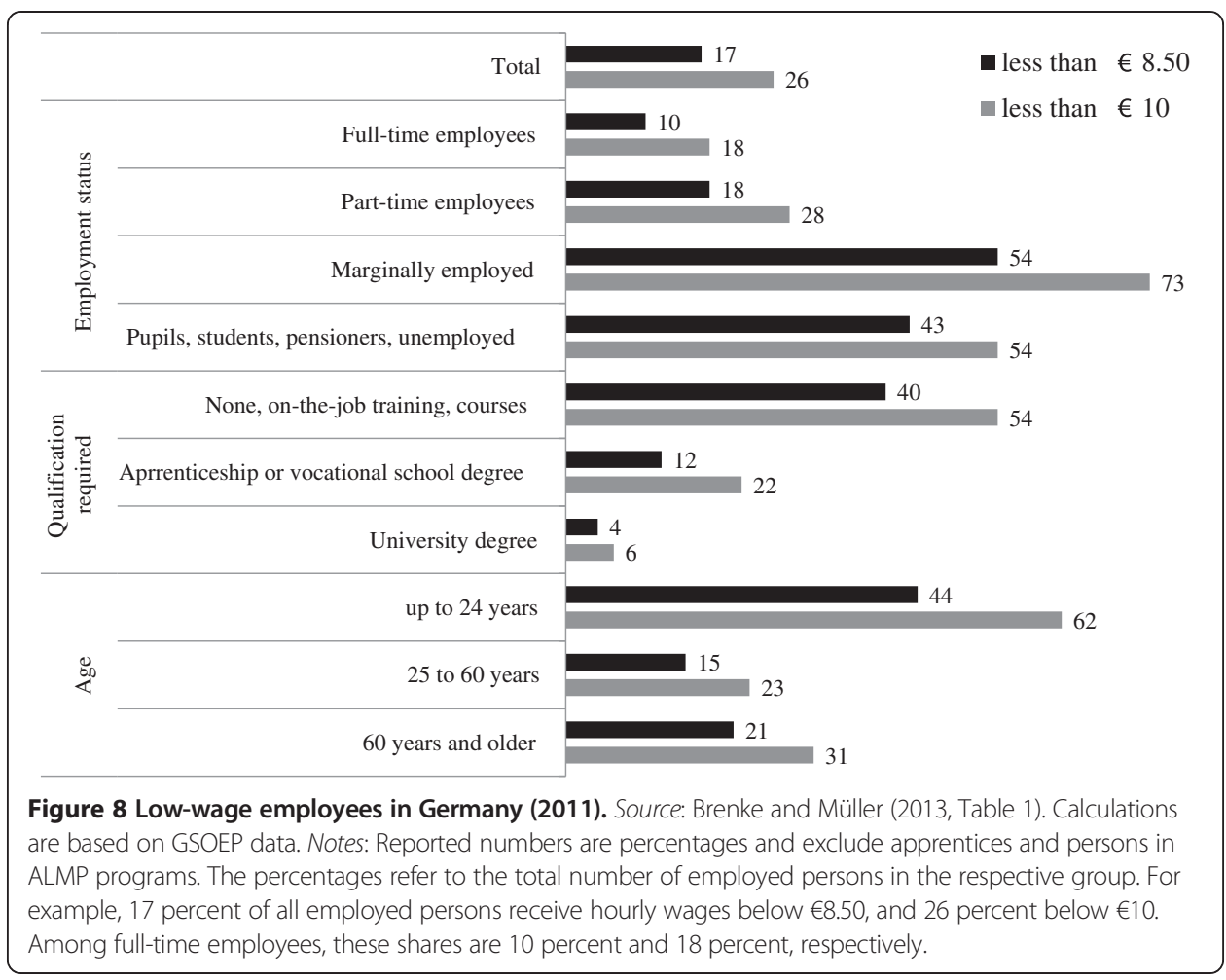

pupils, students, pensioners, unemployed, employees in jobs requiring no formal qualifications and younger workers.

As a result, even a relatively high minimum wage of $€ 10$ would reduce income inequality only by 1 percent (Brenke and Müller, 2013). There are a number of reasons why this is the case. Low-wage employees are not concentrated in poor households, but are rather distributed along the net household income distribution. Many are secondary earners contributing additional income to relatively rich households. Hence, the effects of a minimum wage would be cushioned by the tax and transfer system as many low-wage earners face high marginal tax rates. Effects on income inequality would then be even lower assuming that a minimum wage increases the risk of becoming unemployed for the individuals who are affected. Moreover, this increasing risk may be particularly concentrated among young individuals who enter the labor market for the first time.

Ideally, the labor market gradually compensates for inequalities resulting from different initial education levels by allowing non-graduates to acquire professional skills on-the-job. However, this is not the case in France. Unlike many comparable countries, where inequalities resulting from different initial education levels gradually dissolve, the French labor market actually tends to emphasize them. This is related to the strong and increasing segmentation of the French labor market. On the one hand, there are employees in permanent contracts, protected by many rules, which ineffectively protect employees as well as result in very uncertain outcomes for employers, often leading to contentious litigation. On the other hand, there are employees on fixed-term contracts for which the terms and costs are precisely known in advance. Importantly, this dualism has increased since the early 1990s and today more than 90 percent of employees are hired on fixed-term contracts. ${ }^{9}$ 
In France, this segmentation of the labor market affects young people more strongly than in other countries. In 2009 fixed-term employment was five times higher for young people than for adults (Cahuc et al., 2013). In comparison, this ratio is around three for Denmark, the United Kingdom as well as the average in OECD countries. Only in Austria, Germany and Switzerland does this ratio exceed the one in France. As described above, this can be explained by the fact that these three countries have a long tradition of dual apprenticeship systems. In these countries, temporary employment of young people is thus not necessarily synonymous with job insecurity, but rather part of their vocational education.

Historically, the increasing use of fixed-term contracts in France coincided with rising youth unemployment. The reason why a strict separation between permanent and temporary jobs may create additional unemployment is quite obvious. As terminating an open-ended contract is expensive and accompanied by legal complexity which causes great uncertainty, French firms increasingly rely on fixed-term contracts. This type of employment is much easier to handle, and therefore firms are adopting it more and more. Many firms therefore "turn" towards short, or even very short, fixed-term contracts. Therefore, often in between two fixed-term contracts, workers register as unemployed. However, finding a new job takes time, especially when the public employment service is poorly equipped to cope with the permanent inflow of job seekers. Thus, the intensive use of fixed-term contracts tends to inflate unemployment figures. Fixed-term contracts moreover only act as stepping stones towards permanent contracts for qualified workers (Junod, 2006). This causes related problems. For example, workers on fixed-term contracts encounter difficulties finding accommodation or to obtain a mortgage since workers with permanent contracts are preferred.

The French labor market is thus characterized by a high minimum wage and strong segmentation. This hampers school-to-work transitions, particularly for low-qualified youths. While labor market segmentation has also been increasing in Germany, effects on youths are not as detrimental. This can be attributed to labor costs, but to a large extent also to the dual apprenticeship system absorbing many youths during a critical stage of their career.

\section{Activation measures and labor policies}

Many countries have compulsory and specific systems requiring the public employment service to encourage low-qualified young job seekers to resume their studies, apprenticeships or training courses. ${ }^{10}$ No such system currently exists in France. The support of young people between the ages of 16 and 25 who experience difficulties in finding a job is entrusted to "local missions," which are local counseling and placement offices managed by associations. In 2011 these local missions welcomed 1.35 million young people, of whom almost 500,000 were seen for the first time. However, their support is far from intensive. In 2008 only 11 percent of the low-qualified youths had at least one interview per month, and 50 percent had only three interviews in 12 months (DARES, 2010). This is a very unsatisfactory way to build a trusting relationship between the unemployed and local missions. Moreover, almost 40 percent of the young job seekers wait more than one year before going to a local mission; and more than 60 percent who have crossed this threshold are still searching for a job or training position six months later. Organizational structures 
also appear suboptimal as the local missions are mainly autonomous and in a de facto monopolistic situation (Cahuc et al., 2013). Hence, current structures and methods in France dedicated to support young people in difficulty are insufficient.

In general, there are various measures of active labor market policy available that aim to enhance the employment prospects of unemployed youths, but their effectiveness (or performance) is relatively unclear. This is not the case for Germany, where an evaluation study of ALMP draws a rather positive picture (Caliendo et al., 2011). In particular wage subsidies, job search assistance and short- and medium-term training programs yield persistent and stable employment effects for participants. However, public sector job creation schemes are found to be harmful for participants; this finding aligns with international evidence (Card et al., 2010). Caliendo et al. (2011) additionally note that for low-qualified youths, an approach which focuses more strongly on the intermediate objective of participation in further education or training should be considered.

France is furthermore an exception amongst European countries by restricting its minimum income scheme to people who are 25 years and older. Almost everywhere in Europe, young people have access to a minimum income scheme before turning 25 years old. ${ }^{11}$ In France, the consideration of permitting young people under 25 to enter the minimum income scheme has been hindered by the fear of a resulting rise in inactive youths. The consequence is that currently half of the poorest 20 percent of the French population are between 15 and 29 years old (Cahuc et al., 2013). Bargain and Doorley (2013) estimate that with a new system combining transfers to both workless and working poor, the extension of the minimum income to youths under 25 does not create significant disincentive effects. ${ }^{12}$

Disincentive effects are, in particular, unlikely to result if the minimum income scheme is used as a means of activation (i.e., providing income support while at the same time requiring active search efforts or participation in training programs). The examples of Germany and other countries show that minimum income schemes cannot only be used to facilitate the autonomy of young people, but also as a means of activation. ${ }^{13}$

\section{Demographic trends}

Population aging is not unique to European countries yet is a worldwide phenomenon. For example, Asian countries also face this challenge because of policy measures (e.g., the one-child policy in China) or gender preferences (in favor of sons). Lutz et al. (2008) investigate the future paths of population aging that the world's regions are likely to follow. They show that-with the exception of Sub-Saharan Africa-the average population age in all regions of the world will significantly rise until 2100. However, the extent to which populations will age varies across the globe ${ }^{14}$-and also throughout Europe. The fertility rate is an important factor underlying this heterogeneity. Moreover, this rate is crucial when assessing cross-country differences in youth unemployment, as the size of younger cohorts directly determines young people's labor supply.

Figure 9 therefore displays the development of the total fertility rate in the European Union, France and Germany over the last decade. While French fertility has been slightly increasing to values around 2 in recent years, fertility in Germany has been substantially lower, 


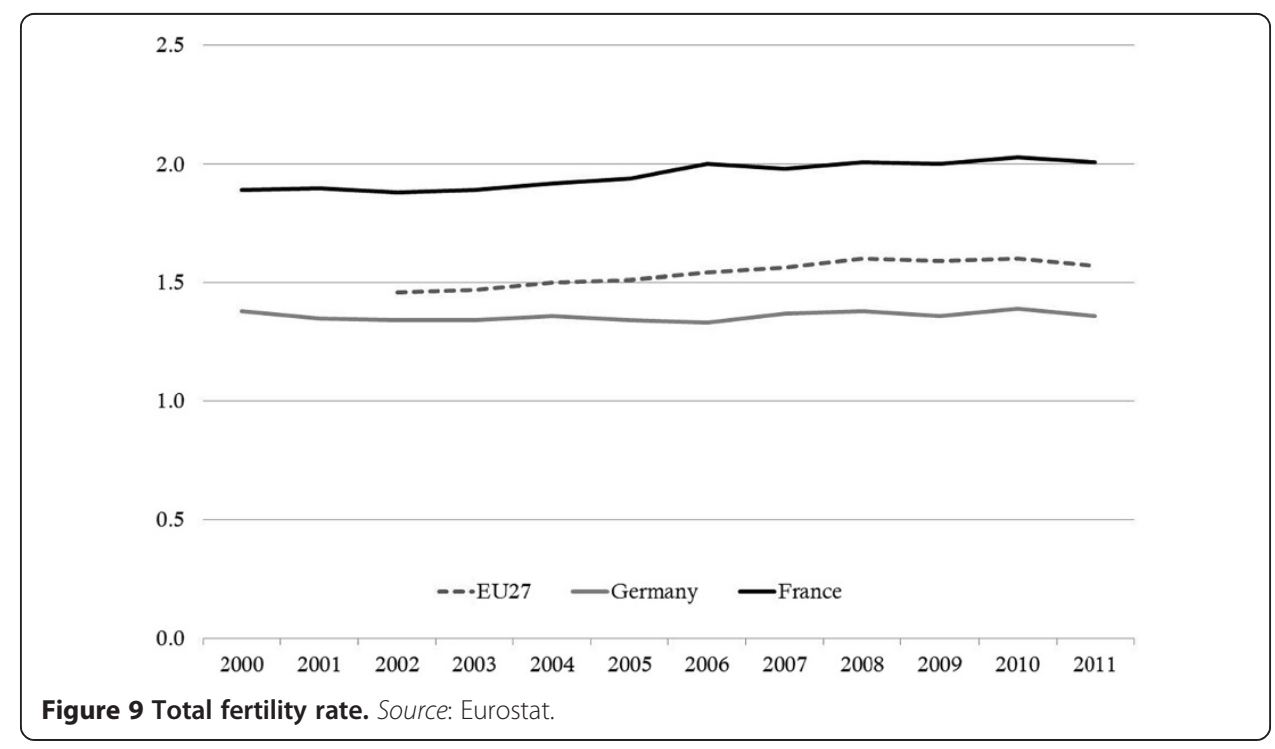

constantly below 1.4. The fertility rate in the European Union lies between the French and the German one, although in recent years it has been slightly increasing to values around 1.6.

As fertility rates are a crucial factor in determining population aging, the projected population sizes by age group look significantly different for the two countries. Future demographic trends put Germany in a relatively advantageous position in terms of youth unemployment when compared to France. ${ }^{15}$ Although this fact should not be neglected when discussing youth unemployment in a comprehensive context (e.g., these trends may influence the current situation of youths to some extent through possible changes in firms' recruitment strategies), the development of recent cohort sizes is clearly more directly related to current youth labor supply.

Figure 10 depicts the proportion of the population that is aged between 15 and 24 years in recent years. In the European Union as well as in France and in Germany, population shares of youths have been decreasing since at least 2007. These decreases are moreover similar in magnitude (about 1 percentage point). Hence, there are no indications that recent changes in

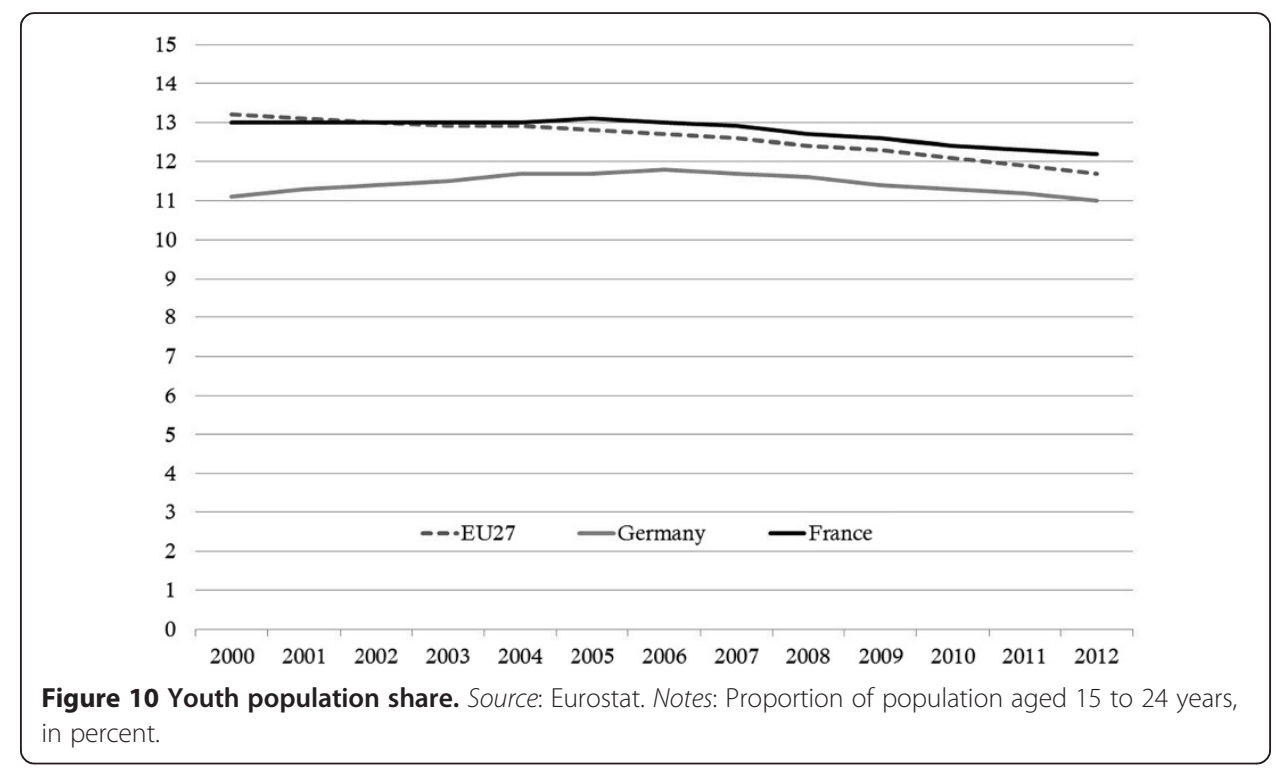


the size of cohorts of labor market entrants play a substantial role in explaining the differences in youth unemployment between France and Germany. Future projections, however, are different for the two countries.

\section{Policy proposals for France}

Although to some extent a number of factors can explain the diverging trend in youth unemployment between France and Germany, the bottom line of this comparison does not change: the situation in France is very alarming and the future prospects of French youths are increasingly dire. This is a socially explosive situation and politicians must act now to avert a lost generation.

There are several underlying causes for this development. First, the share of high-school dropouts is relatively high in France. In fact, one-fifth of these dropouts never graduate. In total there are now over 900,000 young adults in France without a high-school diploma. Second, the strong segmentation of the French labor market is particularly detrimental for young labor market entrants. During the past several years, atypical employment and fixedterm contracts have been five times more common for youths than for adults. Finally, a relatively high minimum wage creates an additional barrier in the access to jobs. In light of these findings, Cahuc et al. (2013) derive a number of concrete policy proposals (see the Additional file 1: Textbox: Proposals to fight youth unemployment in France.).

Cahuc et al. (2013) propose, for example, the implementation of effective activation measures similar to the German principle of "supporting and demanding" (Fördern und Fordern). Current structures and methods in France that are dedicated to support young people in difficulty are insufficient. The public employment service thus needs to be urgently given the means to take charge in a targeted and intensive manner for these young people. Next to establishing regular evaluations by independent experts examining the counterfactual situation ("What would have happened in the absence of the program or intervention?") using modern scientific tools and methods, effective activation measures would include a monitoring program for young people without formal training, as well as a mandatory system of state-sponsored advice and counseling for young job seekers. In addition, a "youth guarantee" scheme should grant basic income support to the age group of 18 to 25-year-olds while at the same time requiring job search efforts or participation in training programs. Moreover, the problem group of school dropouts should profit from a strengthening of existing incompany training programs. Cahuc et al. (2013) also recommend shifting employer training subsidies (e.g., exemptions from social security contributions or financial rewards for offering apprentices permanent employment) towards small and medium-sized enterprises.

More generally, it appears desirable to reduce labor costs for low-skilled youths. This could be done, for example, by increasing the existing reductions of social contributions paid by employers at the minimum wage level, or upgrading the permanent in-work benefit for low-wage workers. A number of studies show that reductions in social security contributions create many more jobs if they are specifically targeted at lower wages (see, e.g., Cahuc and Carcillo, 2012). ${ }^{16}$ This is the reason why a specific targeting at lower wages is essential to the success of a policy aimed at stimulating the creation of low-skilled jobs for young people. Cahuc et al. (2013) also call for an expansion of the "second chance" program. On the other hand, they strongly advise against public employment programs without qualification components. 
Furthermore, at least over the medium term, it is desirable to introduce a dual training system combining school courses with apprenticeships in firms. Such a system is successfully practiced in other countries such as Germany. Because it directly reflects the human capital needs of firms, the dual apprenticeship system paves the way for labor market integration. Therefore in this respect, France would be well advised to emulate the German system.

\section{Policy responses and general lessons at the European level}

Europe's youth unemployment crisis calls for broad policy action. Eichhorst et al. (2013a) illustrate the worrying scope of this problem in the European context, summarize recent policy responses, and discuss additional policy options. To illustrate the dimensions of the problem in Spain, Italy, Greece and Portugal alone (i.e., the countries that are especially affected by the financial and economic crisis), there are currently about two million unemployed persons aged 25 or younger. In the 27 European Union member states, more than 5.5 million young people were out of employment at the end of 2012. These figures clearly underline the urgency to introduce measures tackling youth unemployment both at the national and European level.

At the European level, the European Commission tries to fight youth unemployment to the best of its abilities. This is done primarily through targeted stimulus and by supporting reform measures in the member states, but also through the program "Youth on the Move." This program aims to improve general education, vocational training, higher education, and the mobility of young apprentices and job seekers. Additionally, the support of start-ups and an enhanced labor market entrance of young people in EU countries with above average youth unemployment rates are among the goals of this program (European Commission, 2010).

Furthermore, the EU Commission rightly criticizes high school dropout rates and claims that preventive measures exist which should be applied. At the same time, it advises to strengthen the recognition of informally acquired qualifications by EU member states in order to dually modernize training systems and to offer internships to push early labor market experience acquisition in countries lacking this in the vocational education system. Against the backdrop of increasing qualification requirements, it also calls for stronger efforts to modernize higher education in order to significantly increase the number of graduates across Europe.

This concept is furthermore related to several recommendations and decisions of the EU Commission and the EU Council of Ministers. These proposals not only helped to clearly define the planned measures but also provided the respective funding. At the same time, within the program "Youth on the Move," a European "Youth Guarantee" should be implemented that enables every EU citizen aged between 15 and 24 years to claim the right for employment, vocational training, or participation in a training program. This proposal was inspired by similar approaches in a number of EU countries (e.g., Austria, the Netherlands, Sweden, and Finland). After the European Parliament joined this proposal and called for its legal implementation in January 2013, the "Youth Guarantee" was decided by the EU Ministry Council for Employment and Social Policy (EPSCO) in February 2013 (Eichhorst et al., 2013b). In late June 2013, the EU summit decided to go forward with this concept. However, once converted into national law, EU 
labor market policy will face the huge challenge to provide every young person with (regular or subsidized) work, training, or an internship within four months after graduating or entering unemployment. The "Youth Guarantee" would thus force government authorities in many countries to cooperate more closely with public and private employment services, schools, universities, vocational training providers, employers and unions.

However, there is great danger that the "Youth Guarantee" will lead to disappointment-which will presumably be blamed on the EU-and substantial economic mismanagement. With the prospect of more than 5.5 million unemployed youths in the EU, the member states would have to go to great lengths in terms of designing and coordinating large-scale national programs to fulfill the "Youth Guarantee" even though (or perhaps because) its budget is more than $€ 6$ billion. Experience shows that authorities are tempted to set up extensive public employment and training programs aimed at an immediate effect on unemployment statistics without necessarily creating sustainable employment prospects for the target group.

Hence, instead of devoting organizational efforts and scarce financial resources to this "Youth Guarantee," other key features of the "Youth on the Move" strategy should be pursued. Additionally, the current crisis states should be encouraged to reform their labor markets in a way that would reduce structural disadvantages for young people and promote the creation of new employment. Ultimately, only structural reforms in the respective countries can substantially improve young people's employment prospects. European politics should thus maintain the pressure to reform, but not give "guarantees" and raise expectations that cannot be kept.

This issue can be illustrated by the comparison of France and Germany in this paper. The fundamental differences in youth unemployment between the two countries are primarily the result of structural differences in labor market policies and the (vocational) education system. The Great Recession hit France and Germany differently, but its impact on younger and older age groups was not too markedly different. Hence, any programs that do not aim for (and create) sustainable employment prospects will only lead to temporary relief. While this may be a reasonable (short-term) policy objective given the current dimension of the problem across Europe, it should be very clear that such an approach does not tackle the roots of the problem. The roots of the problem are located in the structural design of national labor markets and education systems. Hence, Europe's youth unemployment disease has to be cured with structural reforms. While the policy proposals for France (see above and Cahuc et al., 2013) can serve as a benchmark, it should be clear that each country has to develop its own concepts since labor market institutions and policies greatly vary across Europe.

\section{Conclusions}

France and Germany are two polar cases in the current debate regarding alarmingly high youth unemployment in Europe. This papers shows that there are several factors that can explain at least part of the significant differences in youth unemployment between the two countries. First, general economic conditions differ as the Great Recession had very different impacts on the French and German labor markets. Whereas the impact in terms of GDP has not been markedly different, the German labor market has shown a remarkable 
resilience to the crisis. Youth unemployment also remained largely unaffected. On the other hand, both adult and youth unemployment strongly increased in France, albeit to a similar extent in relative terms. Second, demographic trends are very different between the two countries. While Germany will face shrinking cohorts of labor market entrants, their number is expected to remain virtually stable in France. This is due to underlying differences in fertility between the two countries. In recent years, however, youth cohort sizes have declined to a similar extent in both France and Germany.

Additionally there are substantial differences between France and Germany in labor market institutions and labor policies. In general, these appear more favorable in Germany with respect to smoothing school-to-work transitions and integrating youths into the labor market. In this context, the established dual apprenticeship system is a very strong German asset. Furthermore, the country has less prominent labor market segmentation than France, and in addition, a national statutory minimum wage has so far not been introduced. Finally, the German approach of the public employment service towards youths appears more efficient in activation than what is currently in practice in France. Hence, when thoroughly considering the factors determining youth unemployment, the strikingly different patterns which France and Germany recently display appear less surprising than at first sight. While it is beyond the scope of this paper to quantify the exact role of each factor, we highlight the importance of labor market institutions and labor policies. These are also the areas in which policy can act-although it should be clear that even the best-designed policy action will not lead to immediate improvements in every case.

It is moreover crucial to thoroughly consider the interactions between labor policies and institutions (e.g., the interaction between vocational education and labor market segmentation). One explanation for the strong segmentation of the French labor market that particularly affects youths can be seen in the country's vocational education system. Temporary employment only acts as a stepping stone towards permanent contracts for qualified workers. Hence, in addition to making permanent contracts more attractive, it also seems important to provide youths with sufficient qualifications. It therefore may be viewed that Germany's dual apprenticeship system could be one factor preventing labor market segmentation in France-at least to some extent.

One important general lesson from our comparison is that efficient labor markets are a crucial factor to effectively fight youth unemployment. More efficiency in this regard then calls for structural labor market reforms. This should be accompanied by labor policy with a targeted approach towards youths, for example, strategies involving activation measures. Establishing a vocational training system combining theoretical dimensions in specialized schools with practical work experience in the private sector appears to be the most effective way to smooth school-to-work transitions. Although such a dual apprenticeship system cannot be implemented overnight, as it relies on a broad support of society, the process of gearing efforts towards its implementation can be started today. Finally, it should be noted that more efficient labor markets and more employment may come at the cost of more inequality. In the German case, the solution to this fundamental trade-off has been to balance these aspects over a person's working life, in particular by providing solid fundamentals, i.e., skills and qualifications, through the dual apprenticeship system. ${ }^{17}$ In general, a key factor to avoiding (too much) inequality is education. 
While it is crucial to fight youth unemployment in Europe in the short run, many possible improvements can only be achieved in the long run. This includes, among other things, the introduction of dual apprenticeship systems in countries other than Germany, Austria and Switzerland. However, short-term improvements of the status quo, which improve the current situation of unemployed youths, can only be achieved through costly labor policy measures. This includes, for example, a targeted and intensive activation strategy by public employment services. This strategy could be combined with offering (subsidized) training or employment, both of which should importantly be provided by private sector companies. Broad international evidence shows that the provision of employment opportunities in the public sector should be avoided. Private sector work experience paves the way for labor market integration because it directly reflects the human capital needs of firms.

Importantly, this approach does not need to be restricted-and should not be restricted-by national borders. Geographic mobility is a very important channel through which youth unemployment can be reduced in the short-run. Countries like Germany could make an important contribution by training and employing young job seekers from other EU countries until their prospects at home have improved.

In a broader policy context, the German success story over the last decade-i.e., the country's remarkably quick turn from "the sick man of the Euro" into "Europe's engine"raises the question of what other countries can learn from this process. Rinne and Zimmermann (2013) argue that although, in general, it is not possible to directly replicate this success story, there are many features of the German model that other countries should closely investigate. For example, measures that increase the overall functioning of the labor market, e.g., only implementing ALMP measures that prove effective as well as improving the overall efficiency of public employment services, should be considered by other countries. However, one should resist the temptation of believing in a one-size-fits-all solution. Instead, models for a given context have to be developed, which can be inspired by several aspects of the German model. In fact, to copy and steal what works in other countries is the bottom line of evidence-based policymaking-and also of the German experience.

Finally, one should also mention in this context that there is also scope to reform the German model. With respect to youth unemployment, for example, its dual apprenticeship system is nowadays regarded as a role model for many countries. However, only a couple of years ago the same model was broadly regarded as an old-fashioned and inflexible model rooted in medieval, guild-based structures. This criticism is at least partly still valid. Inherently, the system can only slowly adapt to changing labor market needs, especially with regards to new occupations that emerge. Furthermore, the German education system can still be regarded as a system allowing for only limited inter-generational mobility. Also the share of pupils leaving the education system without a formal degree is still too high.

\section{Endnotes}

${ }^{1}$ The global youth unemployment rate, i.e., the unemployment rate of all young individuals aged 15 to 24 years in all developed and developing regions of the world, stood at 12.4 percent in 2012, which corresponds to an increase of about 1 percentage point since 2007 (ILO, 2013). 
${ }^{2}$ The duration of the training can be reduced to two years due to other (previous) qualifications or due to performance.

${ }^{3}$ Winkelmann (1997) compares training for young workers in the United States and Germany. A more recent survey by Lerman (2013a) also summarizes the returns to apprenticeship training in a number of countries (including Germany). Lerman (2012) reviews studies according to which apprenticeship training can be effective even in the United States. Finally, Lerman (2013b) makes a strong argument in favor of learning from "best practices" in this regard.

${ }^{4}$ Note that not all empirical studies on the effects of minimum wages on youth unemployment find that these effects are necessarily negative. Counterexamples include Portugal and Cardoso (2006) and Hyslop and Stillman (2007).

${ }^{5}$ About 900,000 individuals in France have no formal educational degree (Cahuc et al., 2013).

${ }^{6}$ For example, exceptions are in place for individuals aged under 18 years and apprentices; however, these situations remain marginal.

${ }^{7}$ Minimum wages have been introduced in some sectors, including the construction sector and temporary agency work. Most parties in Germany are currently open to extent the coverage of minimum wages in the future, and some even support a statutory minimum wage of about $€ 8.50$.

${ }^{8}$ Note that Müller and Steiner (2009) calculate higher implicit minimum wages for couples, in particular for those with children; these implicit minimum wages can be as high as $€ 9$ per hour.

${ }^{9}$ Behaghel and Postel-Vinay (2003) show that the chance that an employee on a given date will be unemployed a year later doubled in France from the late 1970s to the late 1990s-but only for those who with less than five years of work experience. This change can be almost entirely attributed to the increased use of fixed-term contracts in the French labor market.

${ }^{10}$ Examples include the September Guarantee in the United Kingdom, the Youth Guarantee in New Zealand, and similar programs in Denmark and Germany. See Section 7 below for a broader discussion of the Youth Guarantee at the European level.

${ }^{11}$ The only other two exceptions are Spain and Luxembourg.

${ }^{12}$ This finding is in line with Gurgand and Margolis (2008) whose conclusions also tend to minimize the "inactivity trap explanation" (except for single mothers).

${ }^{13}$ For example, and in contrast to conventional wisdom, receiving benefits is not associated with lower geographic labor mobility (Tatsiramos, 2009).

${ }^{14}$ According to Lutz et al. (2008), the world's regions that are presumably most strongly affected by population aging are Japan/Oceania, Western/Eastern Europe, the European Soviet Union and the China region. North America is likely to be affected to a somewhat smaller extent, but its population aging will probably still exceed that of Pacific Asia, Latin America and South Asia.

${ }^{15}$ Whereas the French population is projected to increase from roughly 65 million in 2010 to more than 73 million in 2050, the German population is projected to shrink to less than 71 million during this period. Importantly, especially younger age groups are expected to decline in Germany, whereas their size is projected to remain virtually stable in France. However, older age groups are projected to increase in size in both countries until 2050. 
${ }^{16} \mathrm{~A}$ reduction in social security contributions for higher wages results mainly in wage increases and has little effect on employment.

${ }^{17}$ However, it remains to be seen whether this model can be sustained in the future. For example, a system of lifelong learning is underdeveloped in Germany. But it is very likely that providing solid fundamentals at the beginning of a career will soon not be sufficient anymore to prepare individuals for the increasing speed at which labor market needs change.

\section{Additional file}

\section{Additional file 1: Textbox: Proposals to fight youth unemployment in France.}

\section{Competing interest}

The IZA Journal of European Labor Studies is committed to the IZA Guiding Principles of Research Integrity. The authors declare that they have observed these principles.

\section{Acknowledgements}

The authors would like to thank the Editor and the anonymous referee for valuable comments and suggestions. All remaining errors are our own.

Responsible Editor: Martin Kahanec

\section{Author details}

${ }^{1}$ CREST-ENSAE, Ecole polytechnique, IZA and CEPR, Palaiseau, France. ${ }^{2}$ OECD, Sciences Po (Paris) and IZA, The OECD, Sciences Po Paris, France and IZA, Bonn, Germany. ${ }^{3}$ IZA, Bonn, Germany. ${ }^{4}$ IZA, Bonn University and CEPR, Bonn, Germany ${ }^{5}$ Institute for the Study of Labor (IZA), Schaumburg-Lippe-Str. 5-9, 53113 Bonn, Germany.

Received: 16 July 2013 Accepted: 21 October 2013

Published: 25 Nov 2013

\section{References}

Abowd JM, Kramarz F, Lemieux T, Margolis DN (2000) Minimum wages and youth employment in France and the United States. In: Blanchflower DG, Freeman RB (eds) Youth employment and joblessness in advanced countries. University of Chicago Press

Adda J, Dustmann C, Meghir C, Robin J-M (2011) Career progression and formal versus on-the-job training, Working paper Bargain O, Doorley K (2013) Putting structure on the RD design: social transfers and youth inactivity in France. Working Paper Behaghel L, Postel-Vinay F (2003) Insécurité de l'emploi: le rôle protecteur de l'ancienneté en France a-t-il baissé? Economie et Statistique 366(1):3-29

Bell DNF, Blanchflower DG (2010) Youth unemployment: déjà vu? IZA Discussion Paper, No. 4705

Bell DNF, Blanchflower DG (2011a) Youth unemployment in Europe and the united states. IZA Discussion Paper, No. 5673 Bell DNF, Blanchflower DG (2011b) Young people and the great recession. IZA Discussion Paper, No. 5674

Biavaschi C, Eichhorst W, Giulietti C, Kendzia MJ, Muravyev A, Pieters J, Rodríguez-Planas N, Schmidl R, Zimmermann KF (2012) Youth unemployment and vocational training, IZA Discussion Paper No. 6890 (forthcoming in: Foundations and Trends and Microeconomics)

Brenke K, Müller K-U (2013) Gesetzlicher Mindestlohn - Kein verteilungspolitisches Allheilmittel. DIW Wochenbericht 39:3-17

Cahuc P, Carcillo S (2012) Les conséquences des allégements généraux de cotisations patronales sur les bas salaires. Revue Française d'Economie 27(2):19-62

Cahuc P, Carcillo S, Zimmermann KF (2013) The employment of the low-skilled youth in France. IZA Policy Paper, No. 64

Caliendo M, Künn S, Schmidl R (2011) Fighting youth unemployment: the effects of active labor market policies. IZA Discussion Paper, No. 6222

Card D, Kluve J, Weber A (2010) Active labour market policy evaluations: a meta-analysis. Economic Journal 120(548):F452-F477

Clark D, Fahr R (2001) The promise of workplace training for non-college-bound youth: theory and evidence from German apprenticeship. IZA Discussion Paper, No. 378

DARES (2010) L'activité des missions locales et PAIO en 2008, DARES analyses no. 023, direction de l'animation de la recherche, des etudes et des statistiques (DARES)

Eichhorst W, Rodríguez-Planas N, Schmidl R, Zimmermann KF (2012) A roadmap to vocational education and training systems around the world. IZA Discussion Paper, No. 7110

Eichhorst W, Hinte H, Rinne U (2013a) Youth unemployment in Europe: what to do about it? Intereconomics 48(4):230-235

Eichhorst W, Boeri T, Braga M, De Coen A, Galasso V, Gerard M, Kendzia MJ, Mayrhuber C, Pedersen JL, Schmidl R, Steiber N (2013b) Combining the entry of young people in the labour market with the retention of older workers. IZA Research Report 53

European Commission (2010) 'Youth on the move' - an initiative to unleash the potential of young people to achieve smart, sustainable and inclusive growth in the European union. http://europa.eu/youthonthemove/docs/ communication/youth-on-the-move_EN.pdf

Grunau P (2011) Betriebliche Berufsausbildung und Weiterbildung in Deutschland. Institute for Employment Research $(\mathrm{IAB})$, Nuremberg 
Gurgand M, Margolis D (2008) Does work pay in France? monetary incentives, hours constraints, and the guaranteed minimum income. J Public Econ 92(7):1669-1697

Hyslop D, Stillman S (2007) Youth minimum wage reform and the labour market in New Zealand. Labour Econ 14(2):201-230

ILO (2013) Global employment trends for youth 2013: a generation at risk. International Labour Office (ILO), Geneva Junod B (2006) Le CDD: un tremplin vers le CDI dans deux tiers des cas... mais pas pour tous. DARES Study, Paris, №. 117 Kramarz F, Philippon T (2001) The impact of differential payroll tax subsidies on minimum wage employment. J Public Econ 82(1):115-146

Lerman RI (2012) Can the United States expand apprenticeship? Lessons from experience. IZA Policy Paper, No. 46 Lerman, RI (2013a) Skill development in middle level occupations: the role of apprenticeship training. IZA Policy Paper, No. 61

Lerman RI (2013b) Are employability skills learned in U.S. youth education and training programs? IZA Journal of Labor Policy 2 6:1-20

Lutz W, Sanderson W, Scherbov S (2008) The coming acceleration of global population aging. Nature 451(7179):716-719

Müller K-U, Steiner V (2009) Would a legal minimum wage reduce poverty? a microsimulation study for Germany. Journal of Income Distribution 18(2):131-151

Neumark D, Wascher W (2008) Minimum wages. MIT Press

Parey M (2009) Vocational schooling versus apprenticeship training: evidence from vacancy data. Working Paper Portugal P, Cardoso AR (2006) Disentangling the minimum wage puzzle: an analysis of worker accessions and separations. J Eur Econ Assoc 4(5):988-1013

Rinne U, Zimmermann KF (2012) "Another economic miracle? the German labor market and the great recession", IZA journal of labor policy 1. Article 3:1-21

Rinne U, Zimmermann KF (2013) Is Germany the north star of labor market policy? IMF Economic Review, forthcoming doi: 10.1057/imfer.2013.21

Schmillen A, Umkehrer M (2013) The scars of youth: effects of early-career unemployment on future unemployment experiences. IAB Discussion Paper, No. 6/2013

Tatsiramos K (2009) Geographic labour mobility and unemployment insurance in Europe. J Popul Econ 22(2):267-283

Winkelmann R (1997) How young workers get their training: a survey of Germany versus the United States. J Popul Econ 10(2):159-170

10.1186/2193-9012-2-18

Cite this article as: Cahuc et al: Youth unemployment in old Europe: the polar cases of France and Germany. IZA Journal of European Labor Studies 2013, 2:18

\section{Submit your manuscript to a SpringerOpen ${ }^{\circ}$ journal and benefit from:}

- Convenient online submission

- Rigorous peer review

- Immediate publication on acceptance

- Open access: articles freely available online

- High visibility within the field

- Retaining the copyright to your article

Submit your next manuscript at $\boldsymbol{\nabla}$ springeropen.com 